\title{
The Functioning Mechanism \\ of Attributive Metonymy \\ in English Fictional Discourse
}

\author{
Elena V. Anashkina \\ and Olimpiada F. Ivanova* \\ National Research University \\ "Higher School of Economics (HSE)", \\ 20 Myasnitskaya Str., Moscow, 101000, Russia
}

Received 10.05.2016, received in revised form 25.08.2016, accepted 14.09.2016

This paper deals with discursive attributive metonymy. This linguistic phenomenon is clearly opposed to lexical metonymy as it occurs only in discourse and as such has some distinguishing features: nonfrequency, denotation of a situation, semantic discord between the modifier and the modified noun, and expressiveness. This research attempts to provide a comprehensive analysis of the functioning mechanism of discursive attributive metonymy. The findings reveal that metonymic transferences in adjectives are based on different types of contiguity between objects and their attributes and in some cases such contiguity is contextually determined. The functioning mechanism involves asymmetric relations between syntactic and semantic functions of an attribute as well as a syntagmatic shift. Also, in attributive metonymy there occurs recategorization, i.e. adjectives sometimes change their lexicogrammatical class. In terms of cognitive linguistics, the functioning mechanism is based on mapping of different mental spaces resulting in the conceptual integration and blending. In fictional discourse attributive metonymy is a means to create new occasional meanings and expressiveness.

Keywords: attributive metonymy, discourse, contiguity, syntagmatic shift, asymmetric relations, recategorization, conceptual integration, mental space.

DOI: 10.17516/1997-1370-2016-9-10-2315-2327.

Research area: philology.

\section{Introduction}

In linguistics there is a large body of works on attributive metonymy (Novikov, 1996; Lifshits, 2001; Merzliakova, 2003; Sandakova, 2004), although the attention it has received is much less than that for metonymy of nouns. Meanwhile, adjectives, due to their attributive nature, open up ample opportunity for metonymic denominations.
Some linguists believe that attributive metonymy is a more complex phenomenon than metonymy of nouns (Potsepnia, 1997, p.157). Adjectives per se do not have denotations, they correlate with the ones only through the modified nouns. Therefore, semantically adjectives are tied with nouns. Consequently, the mechanism of metonymic transference involves both adjectives and nouns

(C) Siberian Federal University. All rights reserved

* Corresponding author E-mail address: eanashkina@hse.ru, ofivanova@hse.ru 
modified by them. Attributive metonymy is an adjective -plus- noun combination where the adjective syntactically relates to the modified noun but semantically refers to another noun which is either represented in a given context or just implied while the relations between the both nouns are based on contiguity of different types (Arutiunova, 1990, p. 301).

Researchers distinguish between two types of attributive metonymy: lexical (usual, static) and discursive (contextual, dynamic). In this work we study discursive attributive metonymy which still remains under-investigated. So far there is no comprehensive analysis of this phenomenon in English fictional discourse though certain aspects of it have been studied (Osokina, 2003; Kubaeva, 2009). According to Sandakova, discursive attributive metonymy is non-frequent metonymic usage of an adjective in discourse which does not result in a new lexical meaning; it is a condensed denomination of a situation with two participants - implicit and explicit - sharing a common attribute the transference of which causes semantic discord; an occasional combination of the elements in discursive attributive metonymy and multidimensional representation of a situation build up expressiveness (Sandakova, 2004, p. 297).

In this research we aim to provide a comprehensive analysis of the functioning mechanism of attributive metonymy in English fictional discourse. To achieve this, attributive metonymy is investigated in terms of syntagmatic studies, semantic studies, syntactical and grammatical categories as well as cognitive linguistics. Wealso attempt to show how attributive metonymy creates expressiveness in English fictional discourse. Using the continuous sampling method we selected metonymic transferences in adjectives from the works by English-speaking writers of the XIX-XX centuries and analysed them applying the methods of the componential, contextual and conceptual analyses as well as the methods of the definition analysis and syntactic paraphrasing.

\section{Background}

For over more than fifty years Russian linguists have paid attention to contextual attributive metonymic shifts. For the purposes of discussion, the works dedicated to discursive attributive metonymy can be divided into three groups.

The first group is represented by research of attributive metonymy. Researchers studied lexical metonymy and came across contextual attributive metonymy. The latter is referred to as a transferred attribute which syntactically relates to the noun which it does not have semantic relations with (Koroteev, 1964; Wellek, Warren 1984). This transferred attribute conjures the image of its real "owner" and generates a complex semantic body (Dolinin, 1978, p. 157). In our perception the images of two objects with the common attribute co-exist. On the one hand, a new transferred attribute is understood through the attribute of the original noun. On the other hand, characterizing a new object the transferred attribute enriches the original meaning with new semantic elements (Riabtseva, 1973; Dolgikh, 1984; Potsepnia, 1997). The degree of complexity and transformation of the original meaning depends on the character of objects and phenomena which are bound by a common attribute as well as on the frequency of a metonymic model in the language system. The more natural and frequent the proximity between the objects is, the less expressive the transferred attribute is. By contrast, the expressiveness is higher if the metonymic transference of the attribute is based on less frequent or infrequent models.

At the same time such complex semantic body is very succinct as the combination of the object and alien attribute from another adjacent 
object laconically represents a situation (Fedorov, 1985). As a result of the attributive metonymic transference new individual contextual meanings appear which give the reader esthetic experience (Novikov, 1996). Researchers agree that such metonymic epithets, unlike lexical metonymy, perform an expressive function in fictional discourse (Sirotina, 1980).

In linguopoetics attributive metonymy is referred to as word-association metonymy in which the transference occurs only if the objects are contextually (or phonetically) adjacent (Nekrasova, 1975). This peculiar type of discursive attributive metonymy, which is typical solely for poetic discourse, reveals such relations between words where the contiguity is found only at the word level. The contiguity exists between phenomena and categories of poetic discourse, between an image expressed in poetry in different forms and a means of the poetic language (Ocherki istorii iazyka, 1994, p. 194).

The cognitive - discursive paradigm enables the researchers to develop new approaches to studying attributive metonymy and reveal its new important parameters. Chkheidze introduced the terms "static metonymy" and "dynamic metonymy". Static metonymy is defined as common metonymic shift, which correlates with lexical metonymy, and it is opposed to dynamic metonymy. The latter reveals such features as occasionalism, expressiveness and emotional colouring of the metonymic combination and obligatory ties to the context (Chkheidze, 1992, p. 9). Raevskaia also maintains that discursive metonymy functions only within the text and does not exist outside it (Raevskaia 2000, p. 50). The scholar adopts a holistic approach in her studies of discursive metonymy including not only traditional lexical shifts but largerthan-words combinations into this phenomenon. For example, sentences which allow several interpretations (literal and metonymic) due to the cause-and-effect relations of their potential meanings and indirect speech acts in dialogic discourse when one utterance is used instead of another are considered types of discursive metonymy (Raevskaia, 1999). Attributive metonymy is seen as a particular type of discursive metonymy functioning as a transferred attribute. Sandakova (2004) in her research of attributive metonymy in Russian distinguishes between lexical and discursive metonymy and provides a comprehensive description of the latter. The linguist points out that the mechanisms of attributive metonymy in discourse are ellipsis, nominative substitution of the modified noun and a word-building mechanism. To understand and interpret attributive metonymy in fictional discourse the reader should have relevant background knowledge as well as draw on the knowledge about the language and the world and analyse the context.

\section{Discussion}

\section{Contiguity}

Attributive metonymy is based on contiguity (i.e. closeness of association) (Rakhmanova, 1983; Ckheidze, 1992), but the nature of attributes is such that the concept of contiguity typical for the substantive metonymy is not applicable. There are different types of contiguity which is one of the linguistic mechanisms of attributive metonymy.

\section{1) The contiguity of objects}

\section{a) Direct relations between objects}

Sometimes the objects are juxtaposed in the reality which allows them to have a common attribute. The object from which the feature is transferred is, as a rule, not mentioned but only implied:

At that moment music stopped and they went to sit on two chairs against the wall. Leila tucked her pink satin feet under and fanned herself (Mansfield K. Selected stories). 
The objects shoes and feet are naturally adjacent; therefore the attribute pink characterizing Object $_{1}$ (shoes) can characterize Object ${ }_{2}$ (feet) as well.

In other cases the objects are related as the part and the whole. The attribute can be transferred from the part to the whole as well as in the opposite direction. It should be mentioned that the latter is more common. Usually an attribute characterizing a person is transferred to a body part:

He [Birkin] reached and touched the dead face. And the sharp, heavy bruise of ice bruised his living bowels. He wondered if he himself were freezing too, freezing from the inside. In the short blond moustache the life beneath was frozen into a block of ice beneath the silent nostrils. And this was Gerald! (Lawrence, 1996).

\section{b) Indirect relations between objects}

In this case a phenomenon or a situation is described through the emotional state or intellectual properties of the object:

Birkin's heart began to freeze. He had loved Gerald. [...] His brain was beginning to freeze, his blood was turning to ice water. [...] He went over the snow slopes to see where the death had been. [...] Birkin stood high in the painful air, looking at the peaks and the way south (Lawrence, 1996).

The character is depressed because of his friend's death. Looking at the place where the friend had died the man feels pain. His emotions are transferred to the external world which is now characterized through the hero's emotional state.

c) Secondary adjective-formation on the basis of the contiguity of objects

Attributive metonymy of this type results from condensed multi-word combinations. They are based on the adjacency of objects but the attribute is not transferred from Object $_{1}$ to Object $_{2}$. The attribute derives from the name of one of the contiguous objects:

On her way home she usually bought a slice of honey-cake at the baker's. It was her Sunday treat. Sometimes there was an almond in her slice, sometimes not. It made a great difference. If there was an almond it was like carrying home a tiny present $-a$ surprise-something that might very well not have been there. She hurried on the almond Sundays and struck the match for the kettle in quite a dashing way (Mansfield, 1953).

The attributive metonymy almond Sundays can unfold into Sundays when she bought a cake with an almond in it. In fact, in this case not two but three objects are contiguous and one of them is the basis for the attributive metonymy.

\section{The contiguity of the objects' attributes}

Sometimes the contiguity exists not between objects but between attributes. Object ${ }_{1}$ has a set of attributes which are adjacent by default as belonging to one object. One of the attributes of

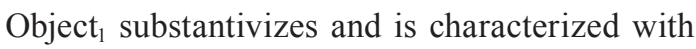
another attribute of this object:

They crowded five of them into the taxi-cab. Halliday lurched in first, and dropped into his seat against the other window. Then Minette took her place, and Gerald sat next to her. They heard the young Russian giving orders to the driver, then they were all seated in the dark, crowded close together, Halliday groaning and leaning out of the window. They felt the swift, muffled motion of the car (Lawrence, 1996).

Object $_{1}$ (car) has such attributes as dark,

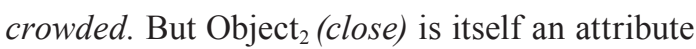
of Object $_{1}-$ a car is seen as a certain enclosure. This attribute substantivizes and is described through the other attributes of Object . $_{\text {. }}$

Sometimes attributes become contextually contiguous as in the following example: 
So she [Ursula] swerved down to the steep, tree-hidden bank above the pond, where the alders twisted their roots. She was glad to pass into the shade out of the moon. There she stood, at the top of the fallen-away bank, her hand on the rough trunk of a tree, looking at the water, that was perfect in its stillness, floating the moon upon it. But for some reason she disliked it. It did not give her anything. She listened for the hoarse rustle of the sluice. And she wished for something else out of the night, she wanted another night, not this moon-brilliant hardness. She could feel her soul crying out in her, lamenting desolately (Lawrence, 1996).

Here, partially, the process is the same as in the previous example: Object $_{2}$ (hardness) is

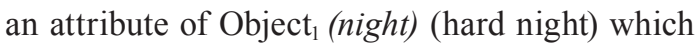
has substantivized and is characterized with another attribute of Object $_{1}-$ moon-brilliant. But the attribute hard does not originally belong to Object $_{1}$ (night), it appears in the context describing the heroine's perception of the night. Thus we see here a twofold metonymic shift where the first level is based on the contiguity of the objects (the heroine - moon-brilliant hard night) and the second level is based on the contiguity of the attributes (moon-brilliant hard night - moonbrilliant hardness).

In conclusion, it should be mentioned that in fictional discourse there are such attributive metonymic transferences which are based on different types of contiguity:

The man went in to drink his can of tea, the girls went on down the lane, that was deep in soft black dust. Gudrun was as if numbed in her mind by the sense of indomitable soft weight of the man, bearing down into the living body of the horse: the strong, indomitable thighs of the blond man clenching the palpitating body of the mare into pure control; a sort of soft white magnetic domination from the loins and thighs and calves, enclosing and encompassing the mare heavily into unutterable subordination, softblood subordination, terrible (Lawrence, 1996).

The attributive metonymy soft white magnetic domination results from a condensed sentence which may be restored as follows:

soft white magnetic domination (from the loins and thighs and calves) -

a blond (white) man with his soft weight magnetically dominated (over the mare).

Now let us track down which components in this restored sentence are contiguous. Firstly, the natural contiguity exists between the objects man and weight (as any material object has weight). From these two adjacent objects two different attributes - white and soft - go into the metonymic transference. Secondly, there is contiguity between the object man and the action dominated performed by the character. The verb turns into a verbal noun in the metonymic complex. Thirdly, in the restored sentence there are syntactic relations between the action dominated and the adverbial modifier of manner magnetically and this combination transforms into the attributive metonymy magnetic domination. Thus, the attributive metonymy results from an originally longer multi-word combination where the noun domination is defined by three different adjectives, each of which reveals a particular type of contiguity.

\section{Syntactic and semantic asymmetry}

The language trichotomy suggests that the ultimate meaning of the utterance is based on three aspects - the form, the denotative meaning and the function (Kobrina, 2000). Ideally, these three criteria should correspond to each other but the symmetry between them occurs not in every case. The asymmetry between the form and the meaning is an inherent property of the language system which manifests 
itself at different levels (Osokina, 2003). One of manifestations of such asymmetry is the transferred attribute which discloses asymmetric relations between its syntactic and semantic functions. The semantic function of the attribute is its contribution to the overall meaning of the utterance while its syntactic function is to modify a noun. In the metonymic transference the attribute belongs to the action or object which it does not syntactically correspond with as in the following examples:

Gatsby and I in turn leaned down and took the small reluctant hand (Fitzgerald, 1973).

Here the adjective reluctant performs the syntactic function of an adjective while its semantic function is to describe the action.

...And now I may dismiss my heroine to the sleepless couch which is the true heroine's portion ... (Austen, 2000).

The transferred attribute sleepless is syntactically connected as modifier with the noun coach but semantically refers to the noun heroine.

In both examples the objects are combined with uncharacteristic and incompatible attributes. Such asymmetric relations are impossible in the reality. Their interpretation requires restoring the primary real relations between objects, actions and their attributes. In other words, it triggers the mechanism of the reader's linguistic creativity.

The transferred attribute can be regarded as a semantic ellipsis (Sandakova, 2004) which is yet another manifestation of the asymmetry between the syntactic and semantic functions. Korovkin defines semantic ellipsis as a process when some semantic elements are shifted to the implicit level accompanied by the structural economy and a multi-word combination turns into a condensed one (Korovkin 2002, p. 214]. The reader again has to return the attribute to its original noun and explicate the metonymic transference to a multicomponent structure:

We were at a particularly tipsy table (Fitzgerald, 1973).

In this transferred attribute the syntactic valence is realized but the semantic valence is not. The adjective tipsy goes together with nouns denoting human beings. But instead of the expected name the adjective combines with the word table which does not possess such a property. The semantic gap between the adjective and the noun can be filled by expanding the transferred attribute to a larger structure (e.g. We were at a table where particularly tipsy people were dining).

Sometimes it seems problematic to unfold a transferred attribute into a multi-component syntactic structure due to the fact that such structure may turn into an artificial or awkward construction:

[..] said Betty [..] looking with uneasy
emotion at the earth displayed so luridly,
with sudden sparks of light from greenhouses
in gardens, with a sort of yellow and black mutability, against this blazing sunset, this astonishing agitation and vitality of colour [...] (Woolf, 1974).

To understand this transferred epithet we need to analyse it trying to get to the core of the author's image:

yellow and black mutability - such change (mutability) in the light of the street when the lit parts (yellow) are followed by the unlit parts (black)

Thus, the mechanism of attributive reader reconstruct the implicit elements. The metonymy is in line with the economy principle in language (Nikitin, 1996). The structural laconism of transferred attributes, on the one hand, and their semantic saturation, on the other, make the implicitness allows a variety of interpretations enhancing a certain image with different associations. All in all, transferred attributes are able to convey more information in a compact 
structure. The asymmetry between the syntactic and semantic functions of attributive metonymy bears evidence of the language elasticity which makes it an extremely flexible tool to convey the most subtle meanings.

\section{Syntagmatic shift}

The basic meaning of the adjective shows a certain syntagmatic potential. The syntagmatic, or co-occurrence, potential is the aggregate of lexical units, each of them being able to combine with a given adjective to denote a situation, as well as the rules of such combinability (Morkovkin, 1984, p. 6). According to Sandakova (2004), the syntagmatic potential of adjective involves, first of all, a quantitative parameter, i.e. the ability to combine with a certain number of nouns, and most adjectives are inherently able to make numerous combinations. Secondly, the co-occurrence means ability / non-ability to attribute particular qualities to several taxonomic classes of nouns, and in this respect there are clear differences between adjectives. So, for example, some adjectives can combine only with nouns within one taxonomic class (e.g. the adjectives corrupt or religious are used to describe qualities of animated objects). Other adjectives are applicable to a greater number of classes of nouns (e.g. long nose, long hours). There are adjectives with a broad compatibility range (e.g. small, big, old, etc.). Here it should be mentioned that the broadest compatibility range is commonly found in adjectives with the meaning of general evaluation.

When adjectives cross the boundaries of their basic co-occurrence and become attributes for nouns of new taxonomic classes, it leads to the metonymic transfer of meaning. When authors deliberately break usual syntagmatic rules with a view to create bright individual and obviously occasional meanings, it results in transferred epithets. Thus, the mechanism of attributive metonymy is based on the syntagmatic shift (Arutiunova, 1998, p. 300).
Nikitin pointed out that attributive metonymy occurs as the result of the deviation from logical subordination (Nikitin, 1996, p. 200):

There he recalls a number of mean dirty shops, and particularly that of a plumber and decorator with a dusty disorder of earthenware pipes, sheet lead, ball taps, pattern books of wall-paper, and tins of enamel (Wells, 2000).

In the original three-member structure with the successive subordination (a disorder of dusty earthenware pipes) the attribute dusty of the object pipes is shifted to the periphery of the word combination and becomes the attribute of the object disorder. Due to this intentional author's deviation from the rules of logical subordination the reader's attention is captured and the context requires creative analysis. In the word combination dusty disorder both components contain the seme untidiness, which is thus enhanced. The meaning untidiness is also supported by the context (the word combination dirty shops, the enumeration of all objects sold in the shop serve to create and intensify the impression of a shambles).

Naturally, any syntagmatic shift is followed by a semantic change. The core meaning of the adjective becomes more complex adding new meanings. For example, the adjective dusty (as in the word combination dusty table) acquires a new semantic component when transferred into the word combination dusty room with the meaning a room where the furniture or other surfaces are covered with dust. Moreover, according to Gak, transferred attributes are characterized by a semantic discord caused by the fact that an object or a phenomenon acquires a distant and alien property (Gak, 1998, p. 285) (see the mentioned above example dusty disorder). Apart from this typical amplification of meaning in transferred attributes, some linguists note that the boundary between the primary meaning of the adjective and its secondary metonymic meaning is very 
often difficult to draw due to the diffuseness of meaning (Sandakova, 2004).

\section{Recategorization}

In attributive metonymy adjectives sometimes change their lexico-grammatical class. Linguists point out that one of the typical characteristics of adjectives is their exceptional semantic mobility, i.e. they easily adapt to the nouns they modify (Bulygina, 1996; Vol'f, 1998). The meaning of the adjective is largely determined by the meaning of the modified noun. When an adjective is separated from a familiar denotation it is shifted into other semantic fields. In attributive metonymy there occurs not only a semantic but, in some cases, lexico-grammatical shift as well.

Semantic classifications of adjectives are numerous with the most general division into qualitative and relative adjectives (Vol'f, 1998), though some researchers consider this division incomplete and inaccurate. According to the classification offered by Arbatskaia \& Arbatskii (1983), all adjectives can be divided into three classes depending on the character of the qualitative meaning:

1) substantive - qualitative adjectives (which, in other classifications, are referred to as possessive adjectives);

2) qualitative - homogenous adjectives (which, in traditional classification, are referred to as relative adjectives);

3) qualitative - gradable adjectives (which are, traditionally, qualitative adjectives).

Recategorization of adjectives is closely related to the nouns which are elements of the attributive metonymy. According to Skliarevskaia (1987), nouns can be classified into the following sematic categories:

1) object;

2) animal;

3) human being;

4) physical phenomenon;
5) psychic phenomenon;

6) abstract concept.

The analysis of the language material reveals that recategorization of adjectives occurs when the attribute is transferred from Object $_{1}$ to Object $_{2}$ given they belong to different semantic categories. If Object $_{1}$ and Object $_{2}$ belong to the same sematic category, the adjective does not change its lexico-grammatical class either. The most often registered shift is the one from qualitative gradable to qualitative - homogenous adjectives:

The children had gone to bed before the garden gate banged and Dicky's father staggered up the steep concrete steps carrying his bicycle. It had been a bad day at the office. He was hot, dusty, tired out. [‥]

"Oh, Edward, I'm so thankful you have come home", she [his wife] cried.

"Why, what's happened?" Edward lowered the bicycle and took off his hat. A red angry pucker showed where the brim had pressed.

"What's up?" (Mansfield, 1953).

In the attributive metonymy the attribute

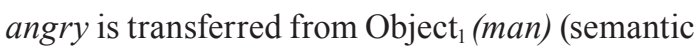
category - human being) to Object $_{2}$ (pucker) (a physical phenomenon) and recategorized from a qualitative - gradable adjective to a qualitative homogenous adjective.

By contrast, in the following example recategorization does not occur:

Still she (Minette) stared into his (Gerald's) face with that slow, full gaze which was so curious and so exciting to him. [...] She wore no hat in the heated cafe, her loose, simple jumper was strung on a string round her neck. But it was made of rich yellow crepede-chine, that hung heavily and softly from her young throat and her slender wrists (Lawrence, 1996).

The attribute young is transferred from Object $_{1}$ (woman) (semantic category - human 
being) to Object $_{2}$ (throat) (the same semantic category). Therefore, the adjective does not change its lexico-grammatical class and remains qualitative - gradable.

\section{Cognitive mechanism}

The complex nature of implicational relations in attributive metonymy allows to study its nature in terms of the theory of mental spaces and conceptual integration. The productivity of this approach to attributive metonymy research has been stressed by Sweetser (1999) and Fauconnier \& Turner (1995, 1999).

According to Fauconnier (1994), mental spaces are arranged sets with elements and their interrelations open to new elements and relations. People analyse not objects and phenomena in accordance with their status in the real world but their cognitive representations which make mental spaces. In other words, mental spaces are models of real or hypothetical situations the way they are conceptualized by human beings.

The theory of mental spaces gave rise to the theory of conceptual integration. Conceptual integration is the basic mechanism of human thinking. As a result of conceptual integration mental spaces are selectively represented in a new construct which is referred to as a blend by Facounnier \& Turner (1996). The blend is not the sum of mental spaces; it is not identical to them. It is a comprehensive, well-integrated compact construct. During conceptual integration all knowledge arrays are involved and mental spaces are constantly reorganized. As Fauconnier (1994) points out, mental spaces are related through coreference referential identity as well as analogic, metaphoric and categorial cognitive mapping.

In attributive metonymy a certain part of a mental space is foregrounded, followed by the process of conceptual integration as we can see in the example below:

To wait, slowly turning over and over in their

old minds the little joys and sorrows, events and expectancies, of their little family world, as cows chew patient cuds in a familiar field

(Galsworthy, 1974).

The attributive metonymy patient cud consists of two elements from two different mental spaces and enables to construct a new mental space. The adjective patient describes behaviour and belongs to the mental space "human being". The modified noun cud belongs to the mental space "cows" and foregrounds such characteristics of cows as deliberation and slow chewing. So, in this attributive metonymy there occurs a mapping of the original categories "food" and "animal" and the category "patience". The contrast based on the opposition "human being" - "animal" is accompanied by the common characteristic "long and slow" which results in the attribute intensification and a new meaning (resignation, passivity).

Thus, in terms of cognitive linguistics, attributive metonymy can be considered as a result of conceptual integration, or mapping of different mental spaces where a part of one of the mental spaces is foregrounded and substitutes the whole space resulting in a new meaning.

\section{Conclusions}

In this paper we investigated discursive attributive metonymy. The findings provide insights into its functioning mechanism. The analysis showed that adjective transference is based on different types of contiguity between the objects and their attributes. The functioning mechanism involves syntactic and semantic asymmetry and a syntagmatic shift. In some cases there is also a lexico-grammatical shift, or recategorization. The cognitive mechanism is based on mapping of different mental spaces resulting in the conceptual integration and blending. In fictional discourse attributive metonymy is a means to create new occasional meanings and expressiveness. The findings may 
be useful in many areas of investigation that deal with metonymy, adjectives, discourse analysis. They may be of interest to teachers and students of English and can be applied in designing courses in theoretical grammar, stylistics and text interpretation.

\section{References}

Arbatskaia, E.D., Arbatskii, D.I. (1983). O leksiko-semanticheskikh klassakh imen prilagatel'nykh russkogo iazyka [On Lexico-Semantic Classes of Russian Adjectives], In Voprosy yazykoznaniya [Issues of Linguistics], 1, 52-65.

Arutiunova, N.D. (1998). Metonimiia [Metonymy]. Iartseva, V.N. (Ed.) Iazykoznanie. Bol'shoI entsiklopedicheskiI slovar' [Linguistics. Encyclopedia]. Moscow, 300-301.

Austen, J. (2000). Northanger Abbey. Kent, Wordsworth Edition, 179 p.

Bulygina, E.J. (1996). Modifikatsiia semantiki ekspressivnogo prilagatel'nogov rechi[Modification of Semantics of Expressive Adjectives in Speech]. Aktualizatsiia Semantiko-Pragmaticheskogo Potentsiala Iazykovogo Znaka [Actualization of the Semantic-Pragmatic Potential of the Language Sign]. Novosibirsk, 40-46.

Chkheidze,V.V. (1992). Ad'ektivnaia metonimiia v poezii A.S. Pushkina: Aftoreferat dissertatsii [Attributive Metonymy in Pushkin's poetry: Author's abstract of a thesis]. St.-Petersburg, $17 \mathrm{p}$.

Dolgikh, I.A. (1984). Aspekty Izucheniia metonimii [Some Aspects of Metonymy Studies], In Vestnik Moskovskogo un-ta, Seriia 9. Filologiia [Moscow state University Vestnik. Series 9. Philology], 4, 52-59.

Dolinin, K.A. (1978). Stilistika frantsuzskogo iazyka [French Stylistics]. St.-Petersburg, 343 p.

Fauconnier, G. (1994). Mental Spaces: Aspects of Meaning Construction in Normal Languages. Cambridge, Cambridge University Press, 256 p.

Fauconnier, G., Turner, M. (1995). Conceptual Integration and Formal Expression, In Journal of Metaphor and Symbolic Activity, 10 (3), 183-204.

Fauconnier, G., Turner, M. (1996). Blending as a Central Process of Grammar, In Conceptual Structure, Discourse and Language. Stanford, California, Center for the Study of Language and Information, 113-130.

Fauconnier, G., Turner, M. (1999). A Mechanism of Creativity, In Poetics Today, 20 (3), 397-418.

Fedorov, A.I. (1985). Obraznaya rech [Tropology]. Novosibirsk, 120 p.

Fitzgerald, F.S. (1973). The Great Gatsby. Kiev, Dnepro Publishers, 180 p.

Gak, V.G. (1998). Iazykovye preobrazovaniia [Language Transformations]. Moscow, 768p.

Galsworthy, J. (1974). In Chancery. Moscow, Progress Publishers, 278 p.

Kobrina, N.A. (2000). Iazyk kak kognitivno-kreativnaia deiatel'nost' cheloveka [Language as a Cognitive-Creative Human Activity]. Studia Lingüistica - 9. Kognitivno-pragmaticheskie $i$ khudozhestvennye funktsii iazyka [Studia Lingüistica - 9. Cognitive-Pragmatic and Expressive Functions of Language]. St.-Petersburg, 23-29.

Koroteev, A.A. (1964). Sintaksicheskie smeshcheniia v sovremennom russkom iazyke: Aftoreferat dissertatsii [Syntactic shifts in the modern Russian language: Author's abstract of a thesis]. Kuibyshev, $28 p$.

Korovkin, M.M. (2002). Kommunikativnyi aspekt ekonomii: implitsiten li sintaksicheskii ellipsis? [The Communicative Aspect of Economy: Is the Syntactic Ellipsis Implicit?]. Tekst $i$ diskurs: 
traditsionnyi i kognitivno-funktsional'nyi aspekty issledovaniia [Text and Discourse: Traditional and Cognitive-Functional Approaches to Research]. Riazan', 209-218.

Kubaeva, F.R. (2009). Kognitivno-semanticheskie kharakteristiki perenesennogo epiteta $v$ angliiskom iazyke: Aftoreferat dissertatsii [Cognitive-Semantic Characteristics of the Transferred Epithet in the English language: Author's abstract of a thesis]. Piatigorsk, 29 p.

Lawrence, D.H. (1996). Women in Love. Penguin Books, 542 p.

Lifshits, G.M. (2001). Vidy mnogoznachnosti v sovremennom russkom iazyke. (Na materiale otsenochnykh imen prilagatel'nykh) [Types of Polysemy in the Modern Russian Language (A Case Study of Evaluative Adjectives)]. Moscow, $200 \mathrm{p}$.

Mansfield, K. (1953). Selected stories. Moscow, Foreign Languages Publishing House, $183 \mathrm{p}$.

Merzliakova, A.H. (2003). Tipy semanticheskogo var'irovaniia prilagatel'nykh polia "Vospriiatie" (na materiale angliiskogo, russkogo i frantsuzskogo iazykov [Types of Semantic Variation in the Adjectives of Perception (A Case Study of English, Russian and French)]. Moscow. 350 p.

Morkovkin, V.V. (1984). Semantika i sochetaemost' slova [Word Semantics and Syntagmatics]. Sochetaemost' Slov i Voprosy Obucheniia Russkomu Iazyku Inostrantsev [Word Syntagmatics and Issues of Teaching Russian as a Foreign Language]. Moscow, 5-15.

Nekrasova, E.A. (1975). Metonimicheskii perenos v sviazi s nekotorymi problemami lingvisticheskoi poetiki [Metonymic Transference in Relation to Some Issues of Linguistic Poetics]. Slovo v russkoi sovetskoi poezii [The Word in Russian Soviet Poetry]. Moscow, 111-131.

Nikitin, M.V. (1996). Kurs lingvisticheskoi semantiki [The Course in Linguistic Semantics]. St.Petersburg, $760 \mathrm{p}$.

Novikov, A.L. (1996). Metonimiia v russkom iazyke (Semanticheskaia struktura. Slovoobrazovatel'nyi potentsial. Stilisticheskie funktsii): Aftoreferat dissertatsii [Metonymy in the Russian Language (Semantic Structure. Word-Formation Potential. Stylistic Functions): Author's abstract of a thesis]. Moscow, $165 \mathrm{p}$.

Ocherki istorii iazyka russkoi poezii XX veka: Tropy v individual'nom stile i poeticheskom iazyke [Essays on the History of the Language of the Russian Poetry in the XX Century: Tropes in Individual Styles and Poetic Language (1994). Moscow, $271 \mathrm{p}$.

Osokina, N.J. (2003). Smeshchennye chleny predlozheniia kak iavlenie sintaksisa i kak stilisticheskii priem): Aftoreferat dissertatsii [Transferred Sentence Parts as a Syntactic Phenomenon and Stylistic Device: Author's abstract of a thesis]. Barnaul, $26 \mathrm{p}$.

Potsepnia, D.M. (1997). Obraz mira v slove pisatelia [The Worldview in the Author's Word]. St.Petersburg, $262 p$.

Raevskaia, O.V. (1999). O nekotorykh tipakh diskursivnoi metonimii [On Several Types of Discursive Metonymy], In Izvestiia RAN. Seriya LiYa [Bulletin of the Russian Academy of Science. Series: Literature and Language], 58 (2), 3-12.

Raevskaia, O.V. (2000). Metonimiia v slove i v tekste [Metonymy in Word and Text], In Filologicheskie Nauki [Philological Sciences], 4, 49-55.

Rakhmanova, L.I. (1983). K voprosu o prirode metonimii [On Nature of Metonymy]. Leksicheskie edinitsy $i$ organizatsiia struktury literaturnogo teksta [Lexical Units and the Organization of the Literary Text Structure]. Kalinin, 70-84. 
Riabtseva, E.G. (1973). Lingvisticheskaia priroda i stilisticheskie funktsii metonimicheskikh tropov (na materiale angliiskogo iazyka): Aftoreferat dissertatsii [Linguistic Nature and Stylistic Functions of Metonymic Tropes (A Case Study of English): Author's abstract of a thesis]. St.-Petersburg, 16 p.

Sandakova, M.V. (2004). Metonimiia prilagatel'nogo v russkom iazyke: Doktorskaia dissertatsiia [Attributive Metonymy in the Russian Language: Doctoral Dissertation]. Moscow, $401 \mathrm{p}$.

Sirotina, V.A. (1980). Metonimiia i metonimicheskii epitet v khudozhestvennoi rechi [Metonymy and Metonymic Epithet in Fictional Discourse], In Russkii iazyk v shkole [The Russian Language in School], 6, 72-77.

Skliarevskaia, G.N. (1987). Iazykovaia metafora v slovare. Opyt sistemnogo opisaniia [Language Metaphor in the Dictionary. The Experience of a Systemic Description], In Voprosy iazykoznaniia [Issues of Linguistics], 2, 58-65.

Sweetser, E. (1999). Compositionality and Blending: Semantic Composition in a Cognitive Realistic Framework. Cognitive Linguistics: Foundations, Score, and Methodology. Berlin, Mouton de Gruyter, 129-162.

Usminskii, O.I. (1996). Sensornye tropy: klassifikatsiia, znachenie, funktsii [Sensory Tropes: Classification, Meaning, Functions]. Tyumen, $150 \mathrm{p}$.

Vol'f, E.M. (1998). Prilagatel'noe [Adjective]. Iartseva, V.N. (Ed.) Iazykoznanie. Bol'shoi entsiklopedicheskii slovar' [Linguistics. Encyclopedia]. Moscow, 397-398.

Wellek, R., Warren, A. (1984). Theory of Literature. Mariner Books, 375 p.

Wells, H.G. (2000). The Door in the Wall. English Story of XX Century: Short Stories. Moscow, Manager, 3-26.

Woolf, V. (1974). Jacob's Room. London, The Hogarth Press, 168 p.

\title{
Механизм функционирования \\ метонимии прилагательных \\ в англоязычном художественном дискурсе
}

\author{
Е.В. Анашкина, О.Ф. Иванова \\ Национальный исследовательский университет \\ «Высшая школа экономики» \\ Россия, 101000, Москва, ул. Мясницкая, д. 20
}

Объектом данного исследования служит дискурсивная метонимия имен прилагательных. Это явление представляет собой нерегулярное метонимическое употребление прилагательного, которое не приводит к образованию нового лексического значения и существует только в дискурсе. Для дискурсивной метонимии прилагательных характерно конденсированное обозначение ситуации, семантическое несогласование компонентов словосочетания, их нестандартное сочетание и, как следствие, экспрессивность. В статье предпринимается попьтка провести комплексный анализ механизма функиионирования метонимии прилагательных в англоязычном художественном дискурсе. Исследование показало, что механизм функционирования основывается на разных типах смежности между объектами и их свойствами, которая во многих случаях существует только в контексте. Асимметричные отношения между 
синтаксической и семантической функииями в дискурсивных метонимических словосочетаниях приводят к синтагматическому сдвигу, т. е. нарушению лексико-семантических норм сочетаемости. В некоторых случаях дискурсивная метонимия прилагательного сопровождается перекатегоризацией, т.е. изменением его лексико-грамматического разряда. В терминах когнитивной лингвистики дискурсивные метонимические сочетания-результат актуализации части ментального пространства и конщептуальной интеграции, что ведет к появлению новых смыслов.

Ключевые слова: метонимия прилагательных, дискурс, смежность, синтагматический сдвиг, перекатегоризация, ментальное пространство, концептуальная интеграџия.

Научная специальность: 10.00.00 - филологические науки. 